\title{
Epigenetic silencing of miR-137 contributes to early colorectal carcinogenesis by impaired Aurora-A inhibition
}

\author{
Yu-Chuan Huang ${ }^{1}$, Chung-Ta Lee ${ }^{5, *}$, Jenq-Chang Lee ${ }^{7, *}$, Yao-Wen Liu ${ }^{8}$, Ying-Jen \\ Chen $^{3}$, Joseph T. Tseng ${ }^{1,2}$, Jui-Wen Kang ${ }^{6}$, Bor-Shyang Sheu ${ }^{6}$, Bo-Wen Lin', Liang- \\ Yi Hung ${ }^{1,2,4,9}$ \\ ${ }^{1}$ Institute of Bioinformatics and Biosignal Transduction, National Cheng-Kung University, Tainan 70101, Taiwan \\ ${ }^{2}$ Department of Biotechnology and Bioindustry Sciences, National Cheng-Kung University, Tainan 70101, Taiwan \\ ${ }^{3}$ Department of Life Sciences, College of Bioscience and Biotechnology, National Cheng-Kung University, Tainan 70101, \\ Taiwan \\ ${ }^{4}$ Center for Infectious Disease and Signal Transduction Research, College of Medicine, National Cheng-Kung University, \\ Tainan 70101, Taiwan \\ ${ }^{5}$ Department of Pathology, National Cheng-Kung University Hospital, Tainan 70403, Taiwan \\ ${ }^{6}$ Department of Internal Medicine, National Cheng-Kung University Hospital, Tainan 70403, Taiwan \\ ${ }^{7}$ Department of Surgery, National Cheng-Kung University Hospital, Tainan 70403, Taiwan \\ ${ }^{8}$ Department of Pathology, Kuo General Hospital, Tainan 70054, Taiwan \\ ${ }^{9}$ Institute for Cancer Biology and Drug Discovery, College of Medical Science and Technology, Taipei Medical University, Taipei \\ 11031, Taiwan \\ *These authors contributed equally to this work \\ Correspondence to: Liang-Yi Hung, email: lyhung@mail.ncku.edu.tw \\ Bo-Wen Lin, email: wen276@gmail.com
}

Keywords: miR-137, Aurora- $A$, COX2, colorectal cancer, epigenetic regulation

Received: May 14, 2016 Accepted: October 12, $2016 \quad$ Published: October 18, 2016

\section{ABSTRACT}

MicorRNA-137 is silenced in human colorectal cancer tissues and colon polyps. Our study showed that the decreased expression of miR-137 is significantly different in various types of polyp which maintain different potentials to lead to CRC development. The expression of miR-137 gradually decreases during the process of colorectal carcinogenesis. Receiver operating characteristic curve (ROC) analysis indicates that the loss of $\operatorname{miR}-137$ expression in colon polyps can serve as a biomarker to predict the predisposition of colorectal carcinogenesis. By cell model and xenograft animal model, the enforced expression of $m i R-137$ in colorectal cancer cells can inhibit cell proliferation and tumor formation, induce G2/M arrest, and lead to apoptosis. The expression pattern of $m i R-137$ and Aurora-A or PTGS2 is negatively correlated in human colorectal cancer tissues and colon polyps. Those effects induced by overexpressed $m i R-137$ can be rescued by the overexpression of Aurora-A. In summary, our study suggests that the loss of $\operatorname{miR}-137$ expression in colon polyps can serve as a biomarker to predict the tendency toward to CRC formation through the impaired inhibitory effect of Aurora-A. The investigation of the regulatory mechanism

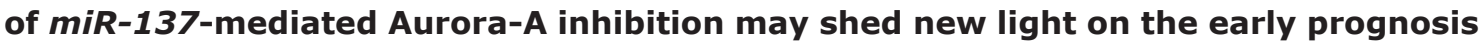
of cancer therapy for CRC in the future.

\section{INTRODUCTION}

Colorectal cancer (CRC) is the third most commonly diagnosed cancer, and the second leading cause of cancer-related deaths worldwide. The five-year survival rate for early-stage CRC is approximately $90 \%$, whereas it decreases to only $12 \%$ for patients diagnosed with late-stage CRC. The development of CRC progresses consecutively in the adenoma-carcinoma pathway, which is a neoplastic pathway involved in the formation of 
various solid tumors. In addition to the neoplastic pathway, the chromosomal instability (CIN) pathway, microsatellite instability (MSI) pathway, $\mathrm{CpG}$ island methylation pathway (CIMP), and serrated neoplasia pathway all have been reported to participate in the formation of CRC individually or concurrently [1-3]. According to clinical observations, only a small population of polyps can develop into CRC; and the formation of conventional adenoma remains the only well-recognized precursor of $\mathrm{CRC}$. The recurrence rate following surgery is $10 \%$ in stage I patients, $30-40 \%$ in stage II patients, and $60-70 \%$ in stage III patients. Therefore, early diagnosis and therapy in colorectal cancer patients has a significant prognostic value, and it is an urgent necessity to identify new biomarkers or specific therapeutic targets for CRC.

Aurora-A is aberrantly overexpressed in various cancer types, including CRC, and plays an important role in the tumorigenesis [4]. Overexpression of Aurora-A disturbs the cell cycle checkpoint, impairs centrosome function and chromosome segregation, induces CIN, and promotes the epithelial-mesenchymal transition (EMT) [5]. All of these effects of overexpressed Aurora-A make it a good target for cancer therapy. Currently, there are several Aurora kinase inhibitors under clinical trials in patients with various solid tumor malignancies and hematologic cancers [4]. Prostaglandin-endoperoxide synthase 2 (PTGS2), also known as cyclooxygenase 2 (COX2), plays a critical role in colorectal carcinogenesis $[6,7]$. The expression of PTGS2 is elevated in CRC tissues. The PTGS2 transgenic mouse has a higher risk than the wild-type mouse to induce the formation of colorectal cancer tumors after treatment with AOM (azoxymethane) [8]. It is believed that the regular use of PTGS2 inhibitors, such as aspirin, can reduce the risk of colorectal cancer [9].

The expression of microRNAs (miRNAs) can be used as biomarkers in the early diagnosis or prognosis of cancers [10]. According to the literatures, miRNAs can be overexpressed or repressed in CRC, and mechanically act as oncogenes or tumor suppressor genes [11, 12]. MiR-137, a tumor suppressor gene, is epigenetically silenced in colorectal cancer [13-15]. Several reports indicated that miR-137 negatively regulates the progression of CRC through directly targeting the oncogenes, such as Musashi-1, paxillin, FMNL2 and Cdc42 [16-19]. In addition, miR-137 may cooperate with other miRNAs to inhibit the growth of CRC [20]. In this report, we identified $m i R-137$ as a potential biomarker to predict the risk of colorectal carcinogenesis. The expression of $m i R-137$ is differentially reduced in different types of colon polyps, the early-stage of precancerous lesions of $\mathrm{CRC}$, with different potencies to $\mathrm{CRC}$ development. The early loss of $m i R-137$ has a higher risk of colorectal carcinogenesis. During colorectal carcinogenesis, miR-137 is silenced through epigenetic regulation. The enforced expression of $m i R-137$ in CRC can repress the cell proliferation and induces cell apoptosis. Therefore, in addition to its role as a biomarker, miR-137 may serve as a therapeutic miRNA in CRC.

\section{RESULTS}

\section{Epigenetic silencing results in the loss of miR-137 expression in colorectal cancer cells and polyps}

We first checked the expression status of $m i R-137$ in human colorectal cancer cell lines and colorectal cancer tissues. The results showed that the expression of $m i R-137$ was almost undetectable in all of the tested colorectal cancer cell lines (Supplementary Figure S1A) and decreased in human colorectal cancer (CRC) tissues compared with the paired adjacent normal mucosa (Figure 1A and Supplementary Table S1). The decreased level of $m i R-137$ showed no difference between the early stage and late stage of CRC (Supplementary Figure S1B). Interestingly, we found that the expression of $m i R-137$ was also decreased in colon polyps, the pre-cancerous lesions of CRC (Figure 1B and Supplementary Table S2). The miR-137 expression level was gradually decreased from normal colon mucosa, polyps to colorectal cancer tissues (Supplementary Figure S1C). These results imply that the loss of miR-137 expression may occur in the early carcinogenesis of colorectal cancer.

According to a previous report, the expression of $m i R-137$ can be epigenetically regulated [13]. We checked the miR-137 genome and found that there are $\mathrm{CpG}$ islands spread throughout the promoter region and miR-137 transcript (Supplementary Figure S2A). When colorectal cancer cells were treated with 5-aza-2'deoxycytidine (5-aza-C), a methyl transferase inhibitor, the expression of $m i R-137$ was induced (Supplementary Figure $\mathrm{S} 2 \mathrm{~B}$ ). The 5-aza-C-induced expression of $m i R-137$ in $\mathrm{CRC}$ cell lines is time dependent (Figure 2A). Methylation-specific PCR (MSP) further confirmed the methylation status of $m i R-137$ in the colorectal cancer cell line HCT116, human polyps and colorectal cancer tissues, whereas both 5-aza-C-treated cells and normal colon mucosa showed an un-methylated pattern of $m i R-137$ (Figure 2B-2D). The expression level of $m i R-137$ in HCT116, human polyps and colorectal cancer tissues was determined by Q-PCR accordingly (Figure 2B-2D). Furthermore, the methylation of miR-137 in human normal mucosa and polyp was quantified by pyrosequencing (Supplementary Figure S3). The results showed that the methylation percentage of human colon mucosa is around $20 \%$, and that of polyps and colorectal cancer tissues is around $40 \%$ to $50 \%$, and the expression level of miR-137 is negatively correlated with the methylation status (Figure 2E). These data suggest that miR-137 is epigenetically regulated during colorectal cancer progression as previously shown $[13,14]$. 
$m i R-137$ targets several important genes that are involved in the tumorigenesis of colorectal cancer

To investigate the effects of $m i R-137$ in colorectal tumorigenesis, we searched its targeting genes through miRanda and TargetScan, confirmed by miRTarBase (Supplementary Figure S4A). MetaCore analysis showed that those potential miR-137-targeted genes are involved in pathways which are involved in cancer development or malignancies (Supplementary Figure S4B). Four known candidate genes, Aurora-A, PTGS2, CDK6 and $C D C 42$, were selected for further validation (Supplementary Figure S4C). By RT-qPCR, the expression of Aurora-A, PTGS2, CDK6 and CDC42 was decreased in miR-137-overexpressing HCT116 and SW480 cells (Figure 3A). The luciferase reporter assay using the $3^{\prime}$-UTR of Aurora-A or PTGS2 mRNAs indicated that the overexpression of $m i R-137$ can down-regulate Aurora- $A$ and PTGS2 (Figure 3B).

We further checked the specificity of $m i R-137$ in targeting Aurora-A and PTGS2 using two mutants of Aurora-A 3'-UTR (Figure 3C, Aurora-A 3'-UTR mt-1 and Aurora-A 3'-UTR mt-2), two mutants of PTGS2 3'-UTR (Figure 3D, PTGS2 3'-UTR mt-A and PTGS2 $3^{\prime}$-UTR mt-B), and a seed region mutant of $m i R-137$ that can complementarily target the Aurora-A 3'-UTR mt-1 and PTGS2 3'-UTR mt-A and mt-B (Figure 3C and 3D, $h s a-m i R-137 \mathrm{mt}$ ). The luciferase reporter assay indicated that wild-type miR-137 can only inhibit the wild-type Aurora-A 3'UTR and PTGS2 3'-UTR but not the mutants of Aurora-A 3'-UTR or PTGS2 3'-UTR, whereas the miR-137 mt can specifically inhibit the Aurora-A 3'-UTR mt-1 (Figure 3C) and PTGS2 3'-UTR mt-A and mt-B (Figure 3D). Furthermore, the expression of Aurora-A and PTGS2 was also decreased in miR-137-overexpressing cancer cell lines (Figure 3E).
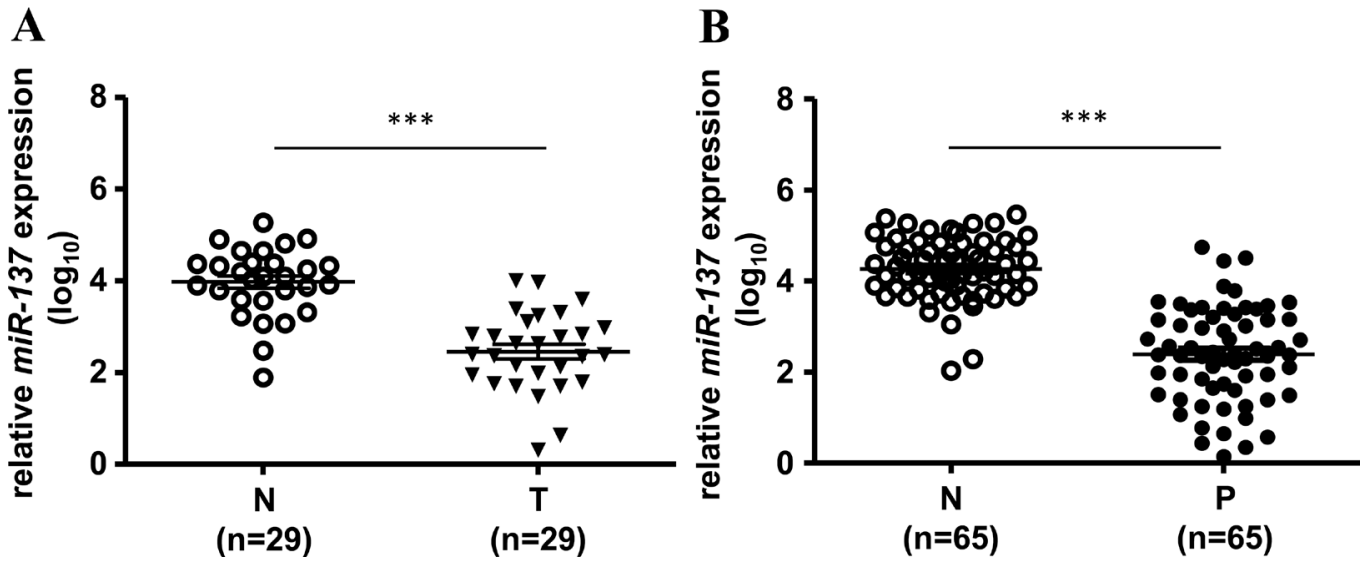

Figure 1: The expression of $m i R-137$ is decreased in human colorectal cancer tissues and colon polyps. The expression level of miR-137 in 29 paired colorectal cancer tissues (T) and adjacent normal tissues (N) (A) or 65 paired colon polyps (P) and adjacent normal tissues $(\mathrm{N})(\mathbf{B})$ was analyzed by TaqMan Q-PCR. ${ }^{* * *} p<0.001$ by Mann-Whitney $U$-test. Bars represent standard deviation of the mean (SEM). 
Table 1: Association between miR-137, Aurora- $A$ and PTGS2 expression with colorectal cancer (Tumor) and (polyp)

\begin{tabular}{|c|c|c|c|}
\hline & $\begin{array}{c}\text { Polyp } \\
(n=64)\end{array}$ & $\begin{array}{c}\text { Tumor } \\
(n=29)\end{array}$ & $p$-value \\
\hline \multicolumn{4}{|l|}{ Age } \\
\hline $30-50$ y/o $(n=9)$ & $9(9.5 \%)$ & $3(3.2 \%)$ & 0.839 \\
\hline $51-80 \mathrm{y} / \mathrm{o}(n=51)$ & $56(59.6 \%)$ & $26(27.7 \%)$ & \\
\hline \multicolumn{4}{|l|}{ Gender } \\
\hline Male $(n=45)$ & $48(51.1 \%)$ & $16(17.0 \%)$ & 0.073 \\
\hline Female $(n=15)$ & $17(18.1 \%)$ & $13(13.8 \%)$ & \\
\hline \multicolumn{4}{|l|}{$\operatorname{miR}-137$} \\
\hline \multicolumn{4}{|l|}{$\left(\right.$ mean $\left.\log _{10}=2.79\right)$} \\
\hline $\operatorname{high}\left(\log _{10}>2.79\right)$ & $39(41.5 \%)$ & $9(9.6 \%)$ & 0.009 \\
\hline low $\left(\log _{10}<2.79\right)$ & $26(27.7 \%)$ & $20(21.3 \%)$ & \\
\hline \multicolumn{4}{|l|}{ Aurora-A } \\
\hline \multicolumn{4}{|l|}{$\left(\right.$ mean $\left.\log _{10}=4.64\right)$} \\
\hline $\operatorname{high}\left(\log _{10}>4.64\right)$ & $23(24.5 \%)$ & $25(26.6 \%)$ & $<0.0001$ \\
\hline low $\left(\log _{10}<4.64\right)$ & $42(44.7 \%)$ & $4(4.3 \%)$ & \\
\hline \multicolumn{4}{|l|}{ PTGS2 } \\
\hline \multicolumn{4}{|l|}{$\left(\right.$ mean $\left.\log _{10}=5.26\right)$} \\
\hline $\operatorname{high}\left(\log _{10}>5.26\right)$ & $31(33.0 \%)$ & $13(13.8 \%)$ & 0.797 \\
\hline low $\left(\log _{10}<5.26\right)$ & $34(36.2 \%)$ & $16(17.0 \%)$ & \\
\hline
\end{tabular}

Bold values indicate statistically significant (Chi square).

and the functional correlation between $m i R-137$ and Aurora- $A$ in the early stage of colorectal carcinogenesis is still unclear, here, we focused on the investigation of the miR-137-Aurora-A axis in colorectal carcinogenesis. To evaluate the effect of $m i R-137$ in tumorigenesis, the IPTG-induced miR-137 HCT116 stable expression cell line was established. After the addition of IPTG, the expression of miR-137 was induced (Supplementary Figure S6) and Aurora-A expression was decreased (Figure 5A). The expression of PTGS2, CDK6 and CDC42 was also decreased in miR-137-expressing stable cells (Supplementary Figure S7). Western blot analysis and immunofluorescence assay showed that phosphorylated histone $\mathrm{H} 3 / \mathrm{S} 10$, which is an indicator of mitotic cells and Aurora-A inhibition, is increased in IPTG-treated $m i R-137$ stable cells (Figure 5A and 5B) or miR-137 transiently transfected cells (Supplementary Figures S8A and S8B). Flow cytometry showed that the overexpression of $m i R-137$ leads to an increase in the $\mathrm{G} 2 / \mathrm{M}$ population of HCT116 or SW480 cells (Supplementary Figure S8C).

Given the effect of Aurora-A inhibition in inducing cell apoptosis, we analyzed the effect of $m i R-137$ expression in apoptosis. The results showed that IPTG treatment induced the activation of Caspase-3/7 in a time-dependent manner in stable cell lines (Figure 5C). The same effects were observed in miR-137 transiently transfected HCT116 or SW480 cells. The cleavage of
PARP and caspase-3 is increased in miR-137-expressing cells (Supplementary Figure S8D). The activities of caspase-3/7 and the sub-G1 population were augmented in miR-137-expressing cells in a time-dependent manner (Supplementary Figure S8E). Both the BrdU incorporation assay and cell proliferation assay indicated that the overexpression of $m i R-137$ can halt the cell proliferation rate (Figure 5E). Interestingly, ectopic expression of GFP-Aurora-A can rescue miR-137-induced proliferative inhibition and cell apoptosis (Figure 5D-5E).

Our previous results showed that miR-137 is epigenetically silenced in cultured colorectal cancer cell lines, and treatment with 5-aza-C can induce its expression (Supplementary Figure S2 and Figure 2A). Consistently, when HCT116 cells were treated with 5 -aza-C, the expression of Aurora-A was decreased and that of cleavage PARP and caspase- 3 was increased, which are the phenomena similar to overexpressed miR-137 (Supplementary Figure S9).

\section{Inducing the expression of $m i R-137$ impairs the tumor growth ability in vivo}

To investigate the effect of overexpressed $m i R$ 137 in tumor progression, miR-137 stable expression cells were used to perform in vivo xenograft animal experiments. The results showed that tumor growth is 
halted in IPTG-induced $m i R-137$ stable cells but not the vector control cells (Figure 6A). The growth of xenograft tumors in mice supplied with IPTG was largely slower than in mice supplied with normal drinking water (Figure 6B). The expression of miR-137 and Aurora-A mRNA in tumors collected from IPTG-treated or untreated mice was determined by RT-qPCR (Supplementary Figure S10A and S10B); the protein expression level of Aurora-A was decreased in tumor tissues from mice supplied with IPTG water (Figure 6C and Supplementary Figure S10C). Immunohistochemistry further showed that Annexin V was increased in tumors from IPTG-treated mice (Figure 6D and Supplementary Figure S10D). These results suggest that enforcing the expression of $m i R-137$ can effectively inhibit tumor growth that may result from the inhibition of target gene expression and induction of apoptosis.

\section{Loss of $m i R-137$ expression can predict the predisposition of colorectal carcinogenesis}

Our previous results showed that the expression level of $m i R-137$ is decreased not only in colorectal cancer tissues but also in colon polyps (Table 1, Figure 1 and Supplementary Figure S1C). It is well recognized that adenomatous polyps have a higher risk than hyperplastic polyps to develop colorectal cancer. Therefore, we checked the correlation with the expression level of miR-137 in adenomatous polyps and hyperplastic polyps. In total, 40 adenomatous polyps (include tubular and villous tubular adenomas) and 20 hyperplastic polyps were collected to analyze the association with the expression level of $m i R-137$. The results showed that miR-137 expression was lower in adenoma but not in the hyperplastic polyps (Table 2 and Figure 7A). When checking the expression
A

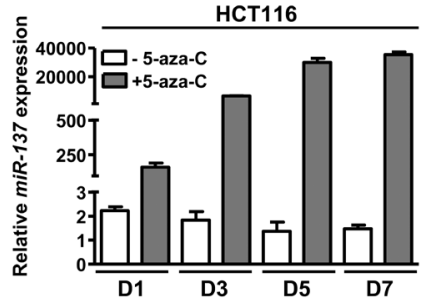

C
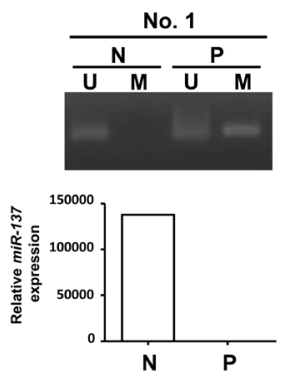

D

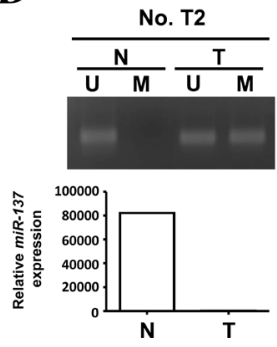

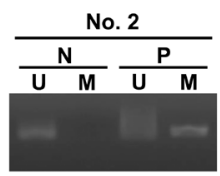
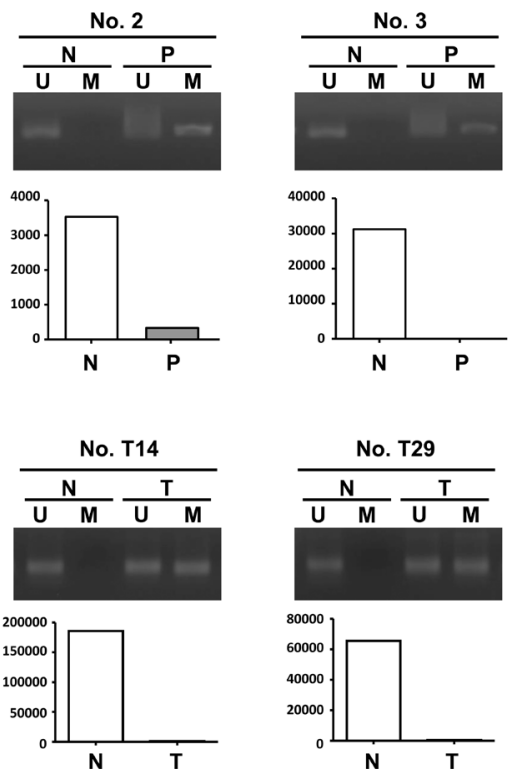

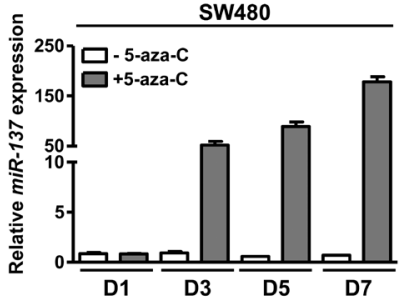

B
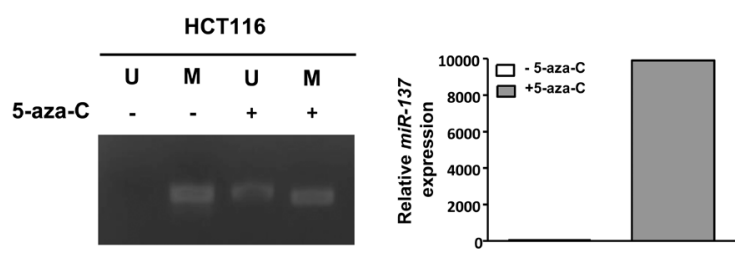

$\mathbf{E}$
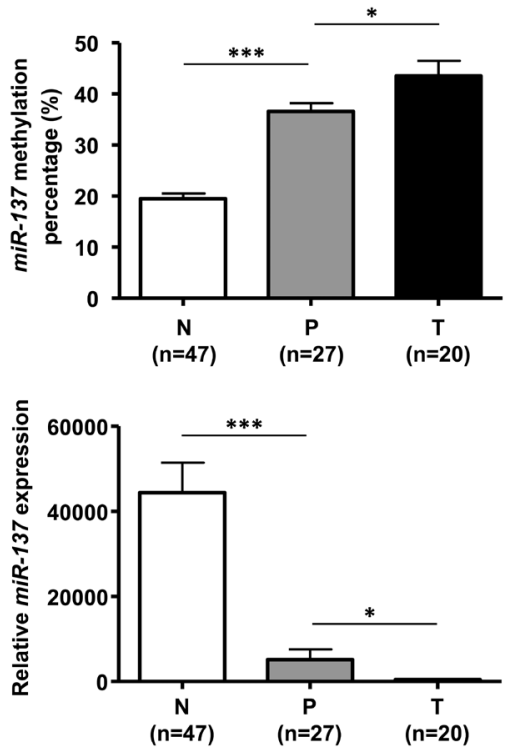

Figure 2: $\boldsymbol{m i R}-137$ is methylated in colorectal cancer cells. (A) HCT116 and SW480 cells treated with (+) or without $(-) 2.5 \mu \mathrm{M}$ 5-aza-CdR for 1, 3, 5, and 7 days (D1, D3, D5 and D7) were harvested to determine the expression of miR-137. (B) HCT116 cells treated with $(+)$ or without (-) 5-aza-CdR for 7 days were collected to analyze the methylation status and expression level of $m i R-137$ by MSP and Q-PCR, respectively. (C-D) The methylation status and expression level of miR-137 in colon polyps (P) (C), colorectal cancer (T) (D) and their adjacent normal tissues (N) were analyzed as described above. Six representative specimens of polyps (No. 1, No. 2 and No. 3) and colorectal cancer tissues (No. T2, No. T14 and No. T29) are shown. (E) Twenty-seven human colon polyps (P), twenty human colorectal cancer tissues $(\mathrm{T})$ and their adjacent normal tissues $(\mathrm{N})$ were collected to check the methylated level (upper) and expression level (lower) of $m i R-137$ by pyrosequencing analysis and Q-PCR, respectively. The quantitative results of the methylated miR-137 are shown as percentages $(\%)$. $* * p<0.001$ and $* p<0.05$ by Mann-Whitney $U$-test. 
Table 2: Association between $m i R-137$, Aurora- $A$ and PTGS2 expression with colon hyperplastic polyps and adenoma polyps

\begin{tabular}{|c|c|c|c|}
\hline & $\begin{array}{l}\text { Hyperplastic } \\
\text { polyp }(n=20)\end{array}$ & $\begin{array}{c}\text { Adenoma } \\
(n=40)\end{array}$ & $p$-value \\
\hline $\begin{array}{l}\text { Age } \\
\qquad \begin{array}{l}30-50 \mathrm{y} / \mathrm{o}(n=9) \\
51-80 \mathrm{y} / \mathrm{o}(n=51)\end{array}\end{array}$ & $\begin{array}{c}3(5.0 \%) \\
17(28.3 \%)\end{array}$ & $\begin{array}{c}6(10.0 \%) \\
34(56.7 \%)\end{array}$ & 0.755 \\
\hline $\begin{array}{l}\text { Gender } \\
\quad \text { Male }(n=45) \\
\text { Female }(n=15)\end{array}$ & $\begin{array}{c}13(21.7 \%) \\
7(11.7 \%)\end{array}$ & $\begin{array}{c}32(53.3 \%) \\
8(13.3 \%)\end{array}$ & 0.206 \\
\hline $\begin{array}{c}\text { miR-137 } \\
\left(\text { mean } \log _{10}=\mathbf{2 . 7 9}\right) \\
\text { high }\left(\log _{10}>2.79\right) \\
\operatorname{low}\left(\log _{10}<2.79\right) \\
\end{array}$ & $\begin{array}{c}20(33.3 \%) \\
0(0 \%)\end{array}$ & $\begin{array}{l}12(20.0 \%) \\
28(46.7 \%) \\
\end{array}$ & $<0.0001$ \\
\hline $\begin{array}{c}\text { Aurora } A \\
\left(\text { mean } \log _{10}=4.64\right) \\
\text { high }\left(\log _{10}>4.64\right) \\
\operatorname{low}\left(\log _{10}<4.64\right)\end{array}$ & $\begin{array}{c}1(1.7 \%) \\
19(31.7 \%) \\
\end{array}$ & $\begin{array}{l}23(38.3 \%) \\
17(28.3 \%)\end{array}$ & $<0.0001$ \\
\hline 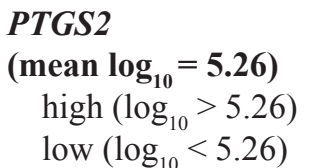 & $\begin{array}{c}1(1.7 \%) \\
19(31.7 \%)\end{array}$ & $\begin{array}{l}26(43.3 \%) \\
14(23.3 \%)\end{array}$ & $<0.0001$ \\
\hline
\end{tabular}

Bold values indicate statistically significant (Chi square).

A

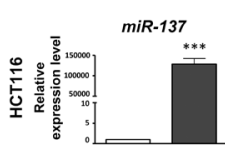

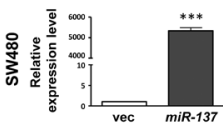

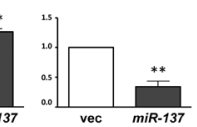

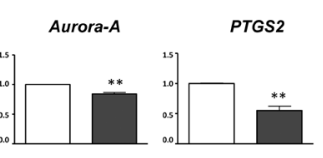
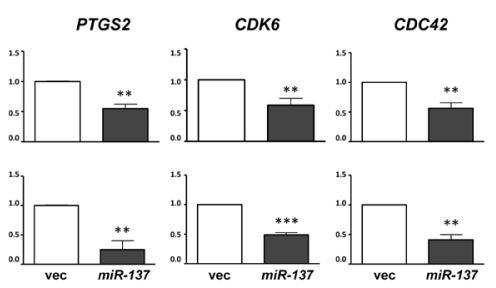

B

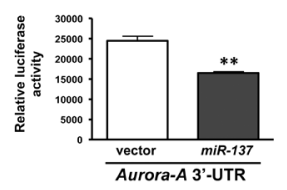

$\mathbf{E}$
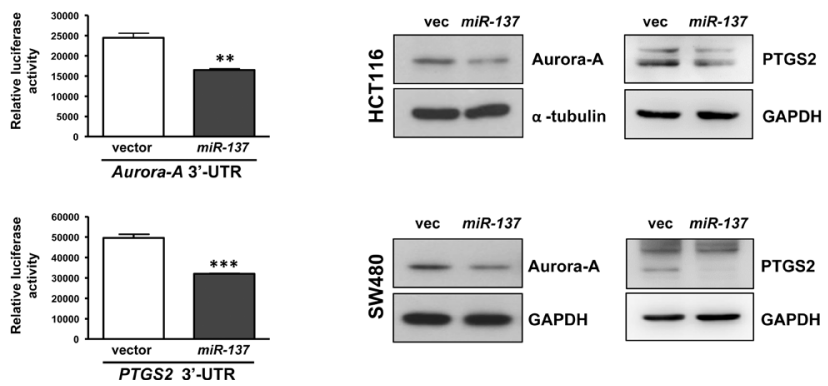

C

\begin{tabular}{|c|c|c|c|}
\hline $\begin{array}{lll}\text { Aurora-A } & 3^{\prime}-\text { UTR } \\
\text { Aurora-A } & 3^{\prime}-\text {-UTR }\end{array}$ & $(374-380)$ & $5^{\prime}$ & CAGUUAAGGAGCUGUGCAAUAAC. \\
\hline $\begin{array}{l}\text { Aurora-A } 3^{\prime} \text {-UTR } \\
\text { Aurora-A } \\
3^{\prime}-\mathrm{UTR}\end{array}$ & $\mathrm{mt}-1$ & & CAGUUAAGGAGCUGGAUAAUAAC. \\
\hline $\begin{array}{l}\text { Aurora-A 3'-UTR } \\
\text { hsa-miR-137 }\end{array}$ & $\mathrm{mt}-2$ & $5^{\prime}$ & . CAGUUAAGGAGCUGGAUGGCAAC. \\
\hline hsa-miR-137 & & 3' & GAUGCGCAUAAGAAUUCGUUAUU \\
\hline hsa-miR-137 (mi & $-137 \mathrm{mt}$ ) & $3^{\prime}$ & GAUGCGCAUAAGAAUCUAUUAUU \\
\hline
\end{tabular}
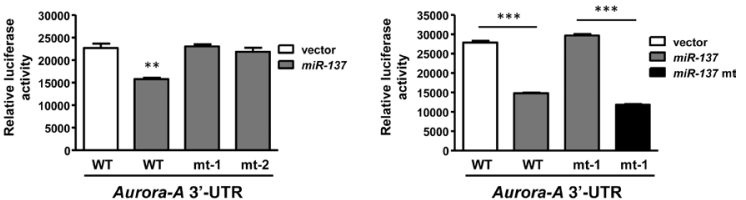

D

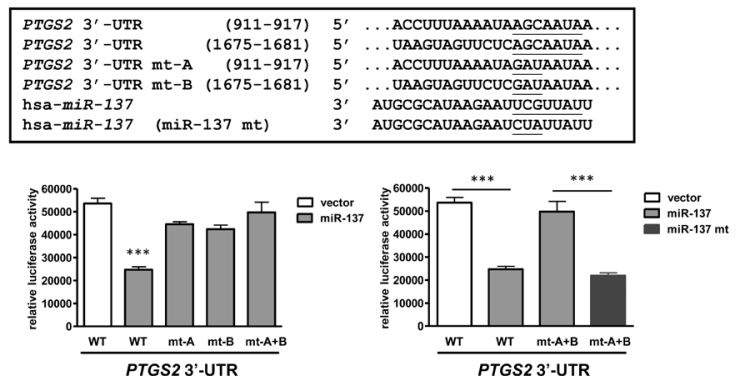

Figure 3: mir-137 specifically targets PTGS2, CDK6, CDC42 and Aurora-A. (A) HCT116 and SW480 cells were transiently transfected with miR-137 or vector control. The expression level of miR-137 and its target genes Aurora-A, PTGS2, CDK6, and CDC42 was determined by TaqMan Q-PCR. (B) HCT116 cells were co-transfected with miR-137 or vector control and Aurora-A 3'-UTR (upper) or PTGS2 3'-UTR (lower), and then the luciferase reporter assay was performed. (C-D) A schematic diagram of Aurora-A 3'-UTR wild type (WT) and mutated sequences (mt-1 and mt-2) (C); and PTGS2 3'-UTR wild type (WT) and mutated sequences (mt-A and mt-B) (D) in the miR-137 targeting site. The miR-137 mutant (miR-137 mt) which complements the Aurora-A 3'-UTR mt-1 and two PTGS2 3'-UTR mutants, mt-A and mt-B, of is shown below. Cells co-transfected with Aurora-A or PTGS2 3'-UTR wild type or mutants and miR-137 or miR-137 mutant (miR-137 mt) were collected for reporter assays to check the specificity of Aurora-A or PTGS2 3'-UTR and miR-137. (E) HCT116 and SW480 cells transiently transfected with miR-137 were collected to determine the expression levels of Aurora-A and PTGS2 by Western blot analysis. 
level in different types of polyps, we found that $m i R-137$ was more decreased in villous polyps, which have a higher risk for CRC development, than in tubular polyps (Table 3 and Figure 7B). Interestingly, the methylation percentage of $m i R-137$ was increased from normal mucosa, tubular polyps to villous polyps (Supplementary Figure S11). ROC (receiver operating characteristic curve) analysis suggested that the loss of $m i R-137$ expression in adenomatous polyps shows excellent discrimination for colorectal cancer formation (Figure 7C). Additionally, the expression level and ROC analysis of Aurora-A mRNA and PTGS2 mRNA in adenomatous polyps and hyperplastic polyps showed
A

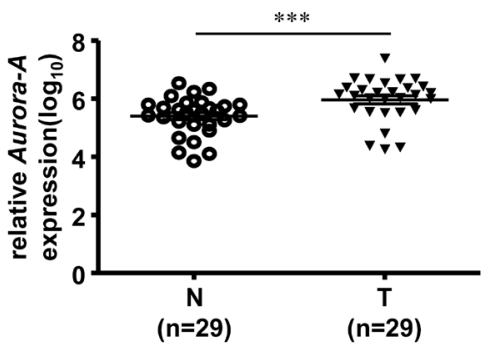

C

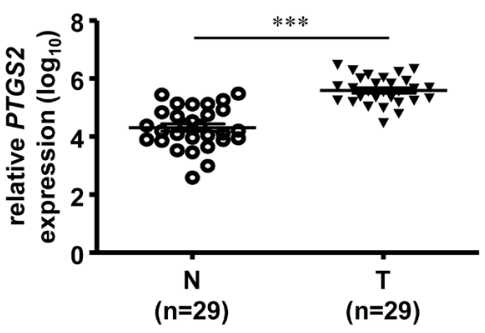

$\mathbf{E}$

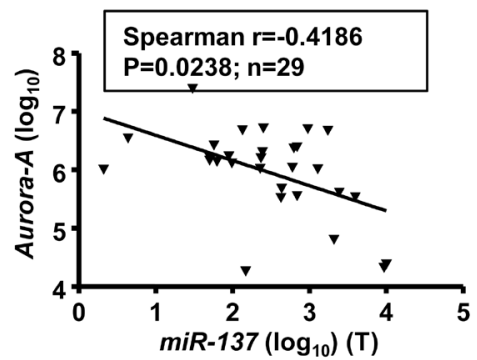

F

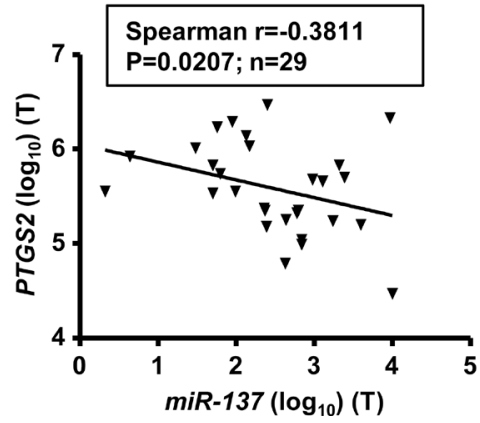

B

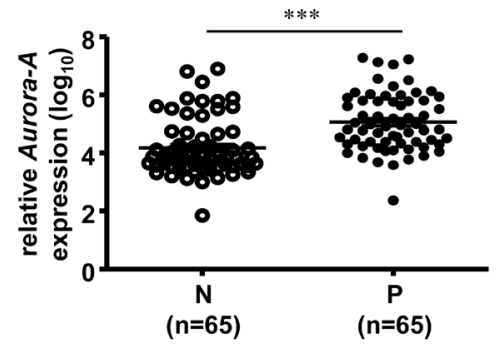

D
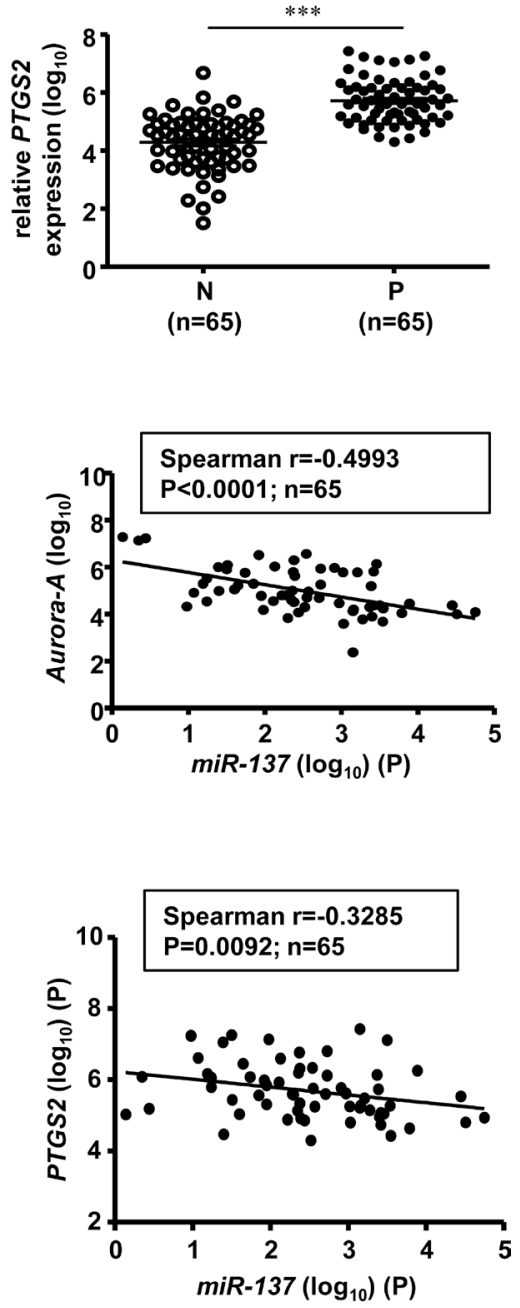

Figure 4: The expression of $\boldsymbol{m i R}-137$ is negatively correlated with Aurora- $\boldsymbol{A}$ mRNA in human colorectal cancer tissues and colon polyps. Total RNA purified from tumorous tissues of CRC (T) $(\mathbf{A}, N=29)$ or colon polyps $(\mathrm{P})(\mathbf{B}, N=65)$ was collected to determine the expression levels of Aurora-A mRNA by TaqMan Q-PCR. The expression level of Aurora-A mRNA is shown as $\log _{10}$. (C-D) The expression level of PTGS2 mRNA was determined by Q-PCR as described above. (E-F) The negative correlation between miR-137 and Aurora-A (E) or PTGS2 (F) in patients with colorectal cancer (left) or colon polyps (right) is shown. The tumorous tissues of $\mathrm{CRC}(\mathrm{T})$ and colon polyps $(\mathrm{P})$ are the same as those in Figure 1. 
Table 3: Association between miR-137, Aurora-A and PTGS2 expression with different types of colon polyp

\begin{tabular}{|c|c|c|c|c|}
\hline & $\begin{array}{c}\text { Hyperplastic polyp } \\
(n=20)\end{array}$ & $\begin{array}{l}\text { Tubular } \\
(n=24)\end{array}$ & $\begin{array}{l}\text { Villous } \\
(n=16)\end{array}$ & $p$-value \\
\hline $\begin{array}{l}\text { Age } \\
\qquad \begin{array}{l}30-50 \mathrm{y} / \mathrm{o}(n=9) \\
51-80 \mathrm{y} / \mathrm{o}(n=51)\end{array}\end{array}$ & $\begin{array}{c}3(5.0 \%) \\
17(28.3 \%)\end{array}$ & $\begin{array}{c}4(6.7 \%) \\
20(33.3 \%)\end{array}$ & $\begin{array}{c}2(3.4 \%) \\
14(23.3 \%)\end{array}$ & 0.461 \\
\hline $\begin{array}{l}\text { Gender } \\
\quad \text { Male }(n=45) \\
\text { Female }(n=15) \\
\end{array}$ & $\begin{array}{c}13(21.7 \%) \\
7(11.7 \%) \\
\end{array}$ & $\begin{array}{c}19(31.7 \%) \\
5(8.3 \%) \\
\end{array}$ & $\begin{array}{c}13(21.7 \%) \\
3(5.0 \%) \\
\end{array}$ & 0.444 \\
\hline $\begin{array}{c}\text { miR-137 } \\
\left(\text { mean } \log _{10}=\mathbf{2 . 7 9}\right) \\
\text { high }\left(\log _{10}>2.79\right) \\
\operatorname{low}\left(\log _{10}<2.79\right) \\
\end{array}$ & $\begin{array}{c}20(33.3 \%) \\
0(0 \%) \\
\end{array}$ & $\begin{array}{l}10(16.7 \%) \\
14(23.3 \%)\end{array}$ & $\begin{array}{c}2(3.3 \%) \\
14(23.3 \%)\end{array}$ & $<0.0001$ \\
\hline $\begin{array}{c}\text { Aurora } A \\
\left(\text { mean } \log _{10}=4.64\right) \\
\text { high }\left(\log _{10}>4.64\right) \\
\operatorname{low}\left(\log _{10}<4.64\right)\end{array}$ & $\begin{array}{c}1(1.7 \%) \\
19(31.7 \%)\end{array}$ & $\begin{array}{l}11(18.3 \%) \\
13(21.7 \%)\end{array}$ & $\begin{array}{c}12(20.0 \%) \\
4(6.7 \%)\end{array}$ & $<0.0001$ \\
\hline $\begin{array}{c}\text { PTGS2 } \\
\left(\text { mean } \log _{10}=5.26\right) \\
\text { high }\left(\log _{10}>5.26\right) \\
\text { low }\left(\log _{10}<5.26\right)\end{array}$ & $\begin{array}{c}1(1.7 \%) \\
19(31.7 \%)\end{array}$ & $\begin{array}{l}12(20.0 \%) \\
12(20.0 \%)\end{array}$ & $\begin{array}{c}14(23.3 \%) \\
2(3.3 \%)\end{array}$ & $<0.0001$ \\
\hline
\end{tabular}

Bold values indicate statistically significant (Chi square).

a comparable result to that of $m i R-137$ (Figure 7D-7E). These results imply that miR-137, Aurora- $A$ mRNA and PTGS2 mRNA have the potential to act as a biomarker to predict colorectal cancer development.

\section{DISCUSSION}

Downregulation of $m i R-137$ was found in many cancers, such as melanoma, head and neck carcinoma, breast cancer, gastric cancer and $\mathrm{CRC}$, by inhibiting cancer cell proliferation, metastasis and invasion [16, 26-29]. In 2010, Balaguer F et al. reported that the epigenetic silencing of miR-137 is an early event in colorectal adenoma [13]. It is well recognized that the adenomacarcinoma sequence is the standard process for colorectal cancer formation from normal mucosa, to adenoma to carcinoma. The formation of colon polyps is the first stage of pre-cancerous lesions of CRC. Our results showed that $m i R-137$ is down-regulated in colon polyps, supporting the conclusion of the early silencing of miR-137 in colorectal adenoma. According to the histological studies, colorectal polyps can be simply classified into two groups-nonneoplastic and neoplastic polyps-according to their malignant potency [30]. Importantly, the expression level of $m i R-137$ is gradually decreased in hyperplastic, tubular and villous polyps (Figure 7B and Table 3). Furthermore, the results from ROC analysis showed that the epigenetic silencing of miR-137 not only occurs in the early stage of the neoplastic pathway but also serves as a biomarker to predict the tendency toward to CRC formation (Figure 7C).
In this study, we found that Aurora-A is overexpressed not only in the tumorous tissues of $\mathrm{CRC}$ but also in the colon polyps (Figure 4B). This is the first report to demonstrate the overexpression of Aurora-A in tissues with pre-cancerous lesions. Our results indicated that the expression of Aurora-A mRNA and miR-137 is inversely correlated in human colorectal cancer tissues and colon polyps (Figure 4C). Although it is reasonable to detect the overexpressed Aurora-A in colon neoplastic tissue polyps, the clinical significance of overexpressed Aurora-A in the early stage of colorectal adenoma remains unclear and needs to be further investigated. Indeed, ROC analysis supports the potential role of Aurora-A in predicting the tendency of CRC development (Figure 7D). In addition to Aurora-A, other potential targets of $m i R-137$ were also characterized, including PTGS2, which also plays an important role in colorectal carcinogenesis [21]. By Q-PCR and ROC analysis, we found that the expression of PTGS2 is negatively correlated with $m i R-137$ in human colorectal cancer tissues and polyps, as well as acts as a biomarker that can predict the tendency toward to CRC formation (Figures 4F and 7E).

It was previously indicated that the overexpression of miR-137 can induce cell cycle G1 arrest in gastric cancer cells through targeting $C d c 42$ [15]. However, in our study, the enforced expression of miR-137 in CRC cell lines induces obvious $\mathrm{G} 2 / \mathrm{M}$ arrest and an increase in phosphor-histone $\mathrm{H} 3 /$ Serine 10 , both of which result from the depressed expression of Aurora-A (Figure 5A, 5B, and Supplementary Figure S8). Importantly, the 
overexpression of Aurora-A in miR-137-expressing cells can reverse those effects (Figure 5D and 5E). The difference between the previous study [15] and this study may be due to the different stages of cancer development. The silenced expression of $m i R-137$ in the early stage of carcinogenesis may contribute to the neoplastic growth through the action of Aurora-A, whereas in the late stage of carcinogenesis, the loss of $m i R-137$ expression can promote cancer cell metastasis by the increased expression of $C D C 42$. Using the xenograft animal model,

A
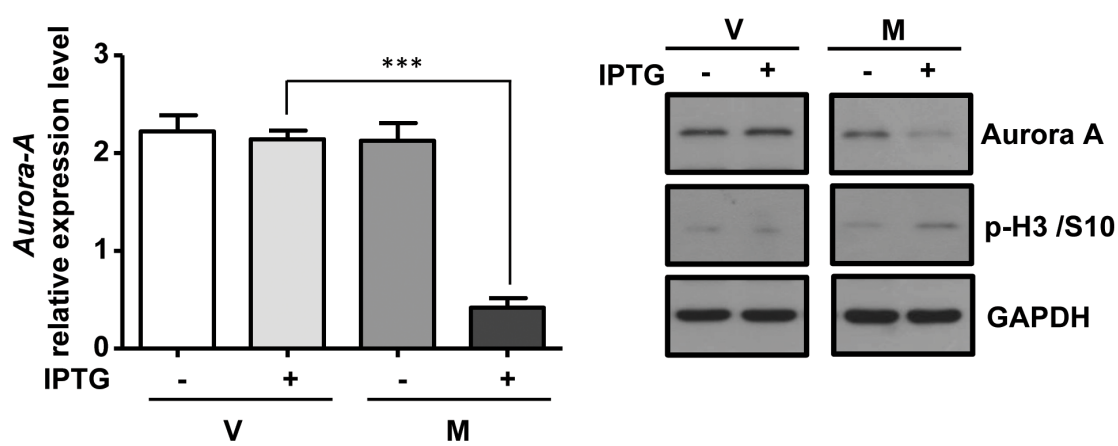

B

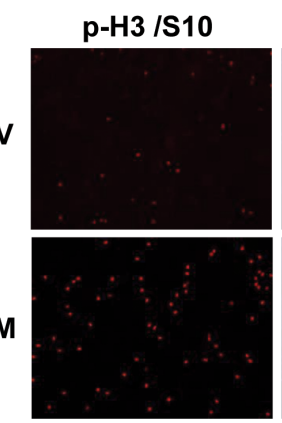

DAPI

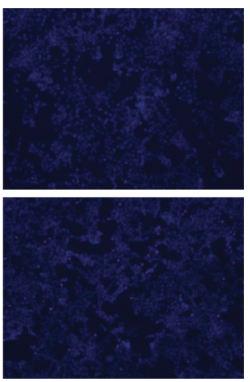

C

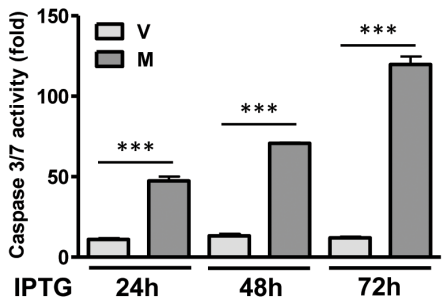

D

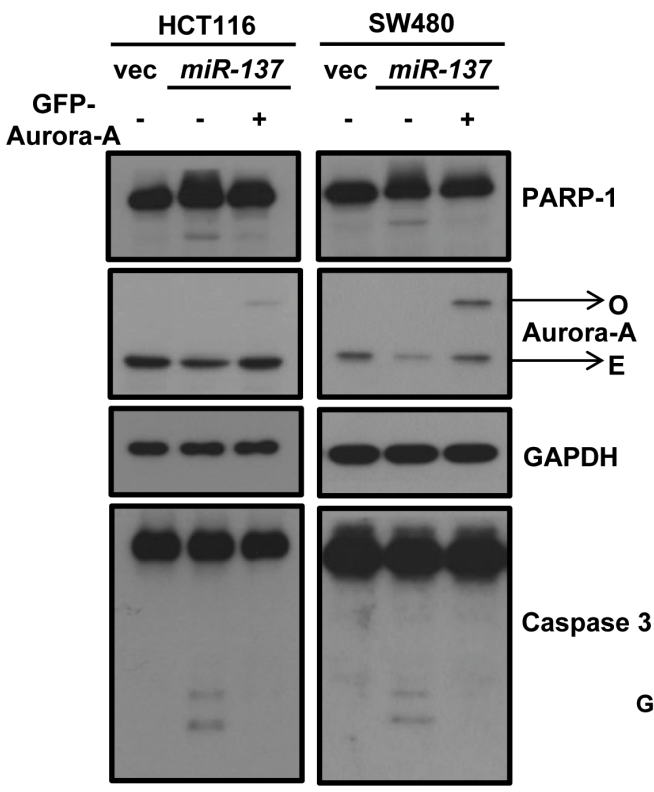

$\mathbf{E}$
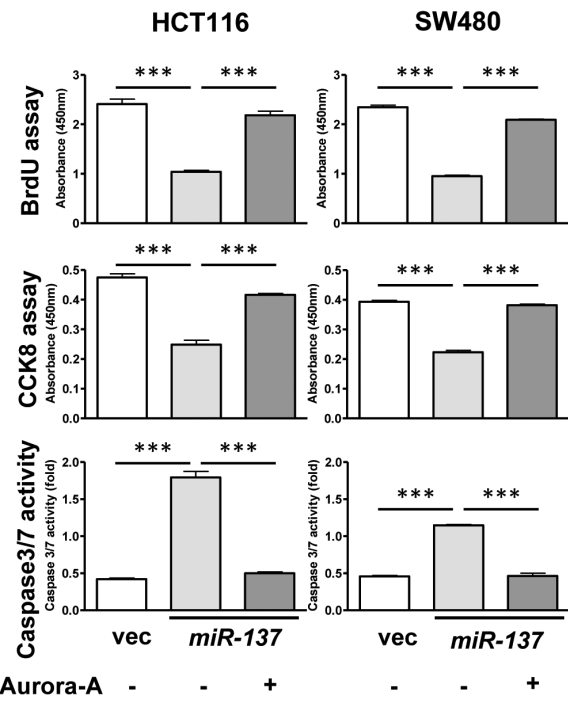

Figure 5: The overexpression of Aurora-A rescues the effect of $\mathbf{m i R}$-137-induced G2/M accumulation and apoptosis. (A-B) Vector control (V) or miR-137 (M) stably expressed HCT116 cells were treated with IPTG for $48 \mathrm{~h}$ to determine the expression level of Aurora-A mRNA (A, left) and protein (A, left). The expression level of phosphor-Histone H3/Ser10 (p-H3/S10) was determined by Western blot analysis (A, left) or immunofluorescence assay (B). (C) Caspase3/7 activity was determined in vector control (V) or miR-137 (M) stably expressed HCT116 cells upon IPTG treatment for $24 \mathrm{~h}, 48 \mathrm{~h}$ and $72 \mathrm{~h}$. (D-E) Vector control (V) or miR-137 (M) stably expressed HCT116 and SW480 cells were transfected with $(+)$ or without $(-)$ GFP-Aurora-A. The cell proliferation ability was determined by the BrdU incorporation assay and CCK8, and apoptosis was detected by measuring the caspase3/7 activity (D). Total cell lysates were collected to perform Western blot analysis using antibodies as indicated (E). 
we demonstrated that the enforced expression of $m i R-137$ can inhibit tumor growth, and the expression of Aurora-A in $m i R$-137-expressing tumor tissues is repressed (Figure 6 and Supplementary Figure S10). These results strongly suggest that the loss of $m i R-137$ expression may promote the neoplastic processing through the impaired ability in Aurora- $A$ inhibition and also imply that $m i R-137$ has the potential to be a therapeutic miRNA.

In conclusion, our study indicates that the epigenetic silencing of miR-137 can occur as

B

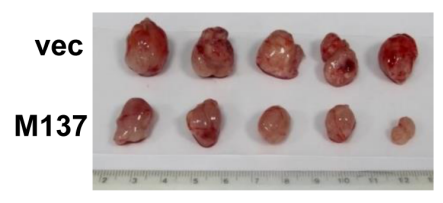

-IPTG

+IPTG
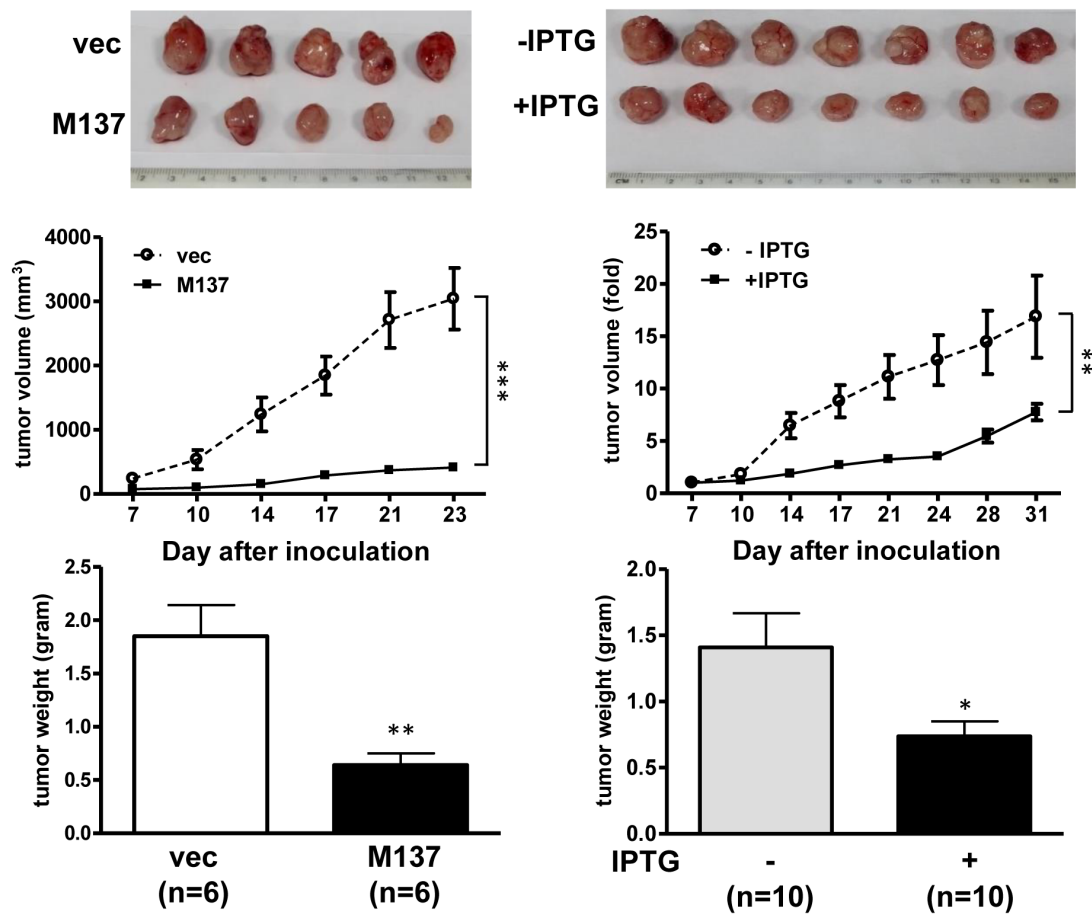

C
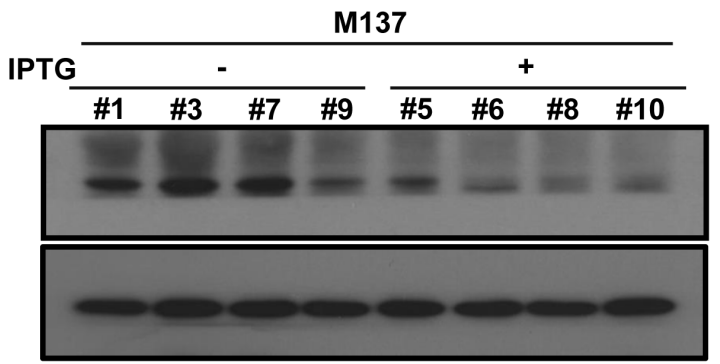

Aurora-A

GAPDH

D

Annexin V

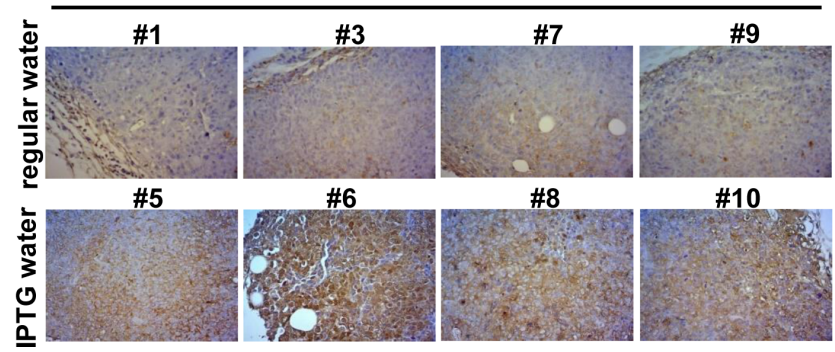

Figure 6: The stable expression of $\mathbf{m i R}-137$ represses the tumor formation ability. (A) A total of $1 \times 10^{6}$ vector- or $m i R-137$ stably expressing HCT116 cells was subcutaneously injected into NOD-SCID mice, and then the mice were supplied with IPTG water. The gross view (upper), tumor volume (middle) and tumor weight (lower) are shown. The tumor volume is calculated using the formula: length $\times$ width $^{2} \times 0.5$. (B) A total of $1 \times 10^{6}$ miR-137-stably expressing HCT116 cells were subcutaneously injected into NOD-SCID mice. After the tumors grew to approximately $100 \mathrm{~mm}^{3}$, the mice were divided randomly into two groups to supply with IPTG water $(+)$ or regular water (-). The growth of the tumors is shown as A. (C) Western blot analysis showed the expression level of Aurora-A in tumor samples from B. (D) Immunohistochemistry analysis showed the expression of Annexin V in tumor tissues obtained from B. 
early as during neoplastic growth, and the loss of $m i R-137$ expression can act a biomarker to predict the predisposition of CRC formation. The expression of miR-137 gradually decreases during the process of colorectal carcinogenesis. Our result provides the clinical significance of $m i R-137$ in the early stage of colorectal cancer development by directly inhibiting Aurora-A and $P T G S 2$ expression. Furthermore, we propose the potential to consider $m i R-137$ as a therapeutic miRNA in cancer therapy.

\section{MATERIALS AND METHODS}

\section{Samples of clinical specimens}

Studies of clinical specimens were conducted according to a laboratory protocol approved by the Institutional Review Board of National Cheng Kung University Hospital (B-ER-103-228), and were in accordance with the Helsinki Declaration of 1975, as revised in 1983.

A

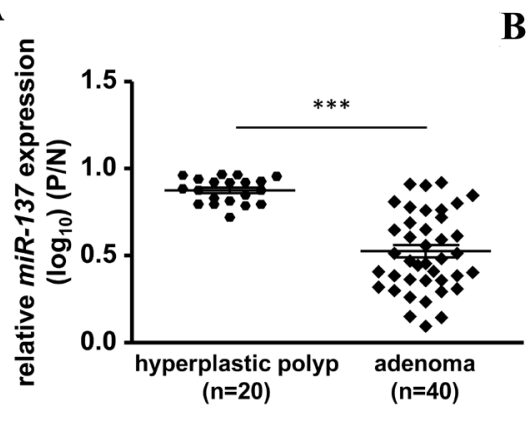

C
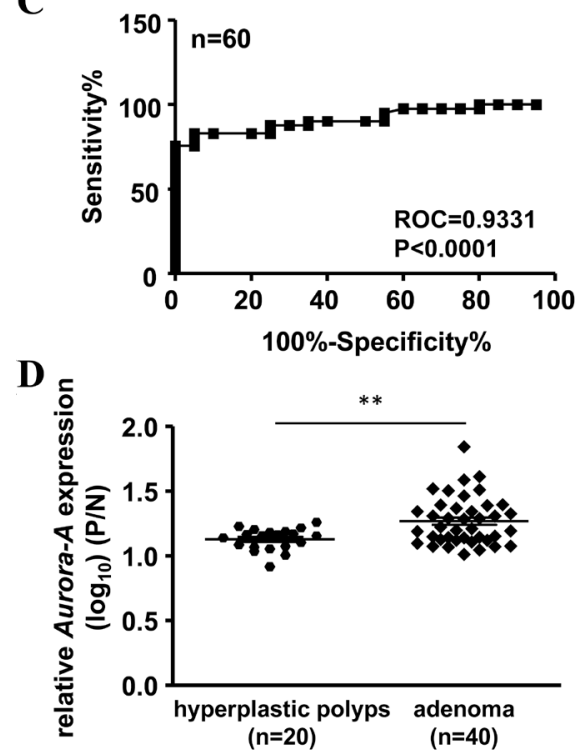

$\mathbf{E}$

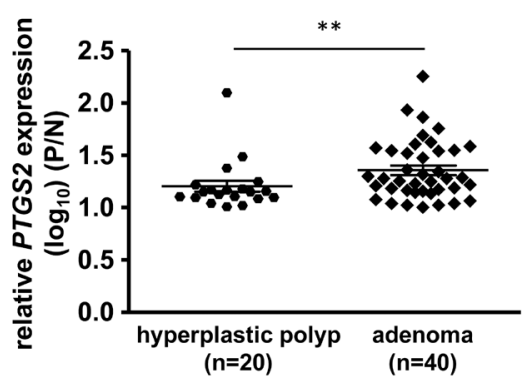

B

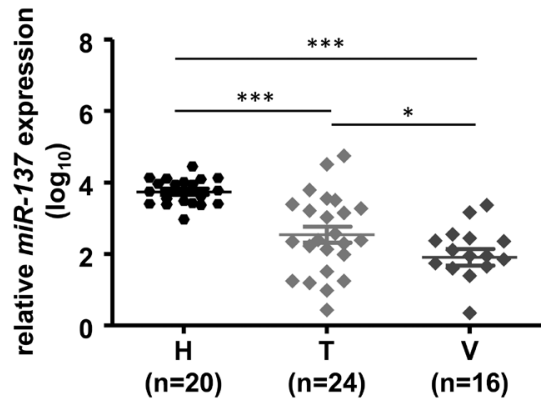

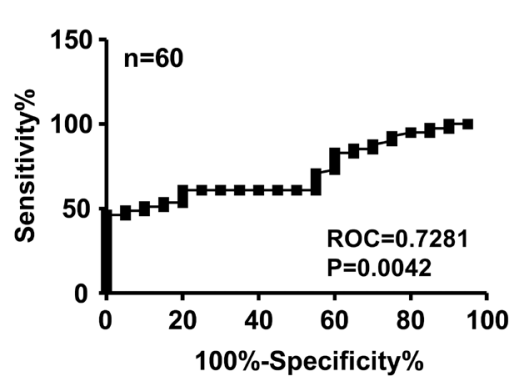

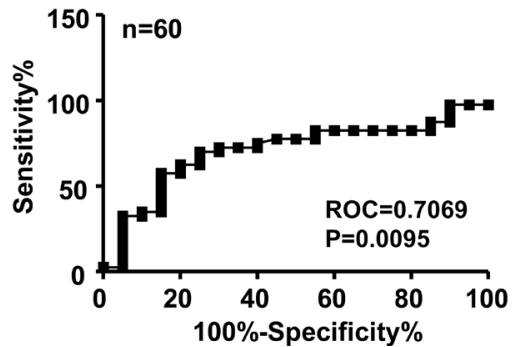

Figure 7: Loss of $m i R-137$ expression may serve as a potential biomarker in colon polyps to predict the predisposition of colorectal carcinogenesis and the potential to be a target for cancer therapy or prevention. (A) The expression level of $m i R-137$ was determined in human colon polyps diagnosed as hyperplastic $(n=20)$ or adenoma $(n=40)$. (B) Expression levels of $m i R-137$ in hyperplastic (H), tubular (T) and villous (V) polyps. (C) ROC curve analysis of $m i R-137$ expression level from (A). (D-E) Expression levels and ROC analysis of Aurora-A (D) or PTGS2 (E) mRNA in human colon polyps. $* P<0.05, * * P<0.01, * * * P<0.001$ by MannWhitney $U$-test. 


\section{Cell culture}

Human colon cancer cells, SW480 cells and HCT116 cells were grown at $37^{\circ} \mathrm{C}$ under $5 \% \mathrm{CO}_{2}$ in 10 -cm plastic dishes containing $10 \mathrm{ml}$ of Leibovitz's L-15 medium and RPMI medium 1640, respectively, supplement with $10 \%$ fetal bovine serum, $100 \mu \mathrm{g} / \mathrm{ml}$ streptomycin, and $100 \mathrm{U} / \mathrm{ml}$ penicillin. The precursor miR-137 was cloned into an IPTG-inducible pLAS1w.3xLacO expression vector (a kindly gift from Dr. Ju-Ming Wang). The stable clones were established in HCT116 cells and selected by $1.5 \mu \mathrm{g} / \mathrm{ml}$ of puromycin. The cells were treated with $62.5 \mu \mathrm{M}$ of IPTG to induce the expression of miR-137.

\section{Total RNA purification and real-time PCR}

The total RNA was extracted using TRIzol reagent (Invitrogen, Carlsbad, CA) according to the manufacturer's instructions. To detect mRNA expression, reverse transcription was performed with $1 \mu \mathrm{g}$ of total RNA using MultiScribe ${ }^{\mathrm{TM}}$ MuLV Reverse Transcriptase (Applied Biosystems, Forster, CA). Real-time PCR was performed using the SYBR Advantage qPCR premix (Bio-Rad, Hercules, CA) in a CFX96 ${ }^{\mathrm{TM}}$ RealTime System and $\mathrm{C} 1000^{\mathrm{TM}}$ Thermal Cycler (Bio-Rad), and the reactions were performed using the following conditions for 40 cycles: $95^{\circ} \mathrm{C}$ for $15 \mathrm{sec}, 60^{\circ} \mathrm{C}$ for 10 sec, and $72^{\circ} \mathrm{C}$ for $5 \mathrm{sec}$. The primer sequences were as follows: forward and reverse primers for human Aurora-A mRNA: 5'-AATGCCCTGTCTTACTGTCATTC-3' and 5'-TCCAGAGATCCACCTTCTCATC-3'; for human PTGS2 mRNA: 5'-CCCTTCTGCCTGACACCTTT-3' and 5'-TTCTGTACTGCGGGTGGAAC-3'; for human CDK6 mRNA: 5'-TCACACCGAGTAGTGCATCG-3' and 5'-CAAGACTTCGGGTGCTCTGT-3'; and for human CDC42 mRNA: 5'-AGGCTGTCAAGTATGT GGAGTG-3' and 5'-GCTCTTCTTCGGTTCTGGAGG-3' . The data were analyzed using Bio-Rad CFX Manager software version 1.5. The relative amount of the target gene was normalized to that of actin of the same cDNA. To detect the expression of miR-137, the cDNA was synthesized using the MicroRNA reverse transcription kit (TaqMan; Applied Biosystems), and the miR-137 and endogenous control U6 small nuclear RNA (snRNA) expression levels were analyzed using the TaqMan microRNA Assay kit (Applied Biosystems) according to the manufacturer's instructions. Briefly, $900 \mathrm{ng}$ of total RNA was combined with $6 \mu \mathrm{l}$ of the RT primer pool (the final concentration was $0.05 \times), 1.5 \mu \mathrm{l}$ of $10 \times$ RT buffer, $0.3 \mu \mathrm{l}$ of $100 \mathrm{mM}$ dNTP mix, $3 \mu \mathrm{l}$ of $50 \mathrm{U} / \mu \mathrm{l}$ MultiScribe Reverse Transcriptase, and $0.19 \mu \mathrm{l}$ of $20 \mathrm{U} / \mu \mathrm{l}$ RNase inhibitor in a total volume of $15 \mu \mathrm{l}$. Each sample was run in individual $0.2 \mathrm{ml}$-tubes using the following parameters: $16^{\circ} \mathrm{C}$ for $30 \mathrm{~min}, 42^{\circ} \mathrm{C}$ for $30 \mathrm{~min}$, and $85^{\circ} \mathrm{C}$ for $5 \mathrm{~min}$, followed by holding at $4^{\circ} \mathrm{C}$. TaqMan Real-time PCR was performed using $2 \times$ TaqMan Universal PCR Master Mix
II, and No AmpErase UNG (Applied Biosystems) in a CFX96 ${ }^{\text {TM }}$ Real-Time System and C1000 ${ }^{\mathrm{TM}}$ Thermal Cycler (Bio-Rad), and the reactions were performed using the following conditions for 40 cycles: $95^{\circ} \mathrm{C}$ for $15 \mathrm{sec}$, and $60^{\circ} \mathrm{C}$ for $1 \mathrm{~min}$. The TaqMan microRNA assay analyzed hsa-miR-137 (Assay ID 001129) and endogenous control U6 small nuclear RNA (Assay ID 001973). The expression of $m i R-137$ was normalized to that of $U 6$ snRNA.

\section{3'-UTR luciferase reporter assay}

The Aurora-A and PTGS2 3'-UTR luciferase constructs were purchased from OriGene Technologies (Rockville, MD). The cells were transfected with $250 \mathrm{ng}$ of pMirTarget-Aurora-A-3'-UTR or pMirTarget-PTGS23'-UTR luciferase construct and $750 \mathrm{ng}$ pMiR-137 or control vector using Lipofectamine 2000 (Invitrogen). Three nucleotides within the miR-137 seed sequence in the pMirTarget-Aurora-A-3'-UTR construct were mutated. After 48 hours, the cells were harvested and assayed using the Dual-Luciferase Reporter Assay System (Promega, Madison, WI). A Renilla luciferase construct was used as a normalizing control for all luciferase assays. Experiments were conducted in triplicate.

\section{Methylation-specific polymerase chain reaction (MSP)}

Genomic DNA from human specimens was isolated using an automated DNA extraction system (QuickGene, Neyagawa-shi, Osaka, JP) according to the manufacturer's instructions, and then the unmethylated cytosine was converted into uracil using the EpiTect Bisulfite Kit (Qiagen, Hilden, Germany). The primer sequences used to analyze miR-137 promoter methylation were designed using Methyl Primer Express Software v1.0 (Applied Biosystems) and were as follows: methylated alleles: 5'-GTAGCGGTAGCGGTAGTAGC-3' and 5'- ACCG CTAATACTCTCCTCGA-3'; unmethylated alleles: 5'GTAGTAGTGGTAGTGGTAGTAGT-3' and 5'-CCTAC CACTAATACTCTCCTCAA-3'. MSP reaction was performed using the following condition for 35 cycles: $95^{\circ} \mathrm{C}$ for $30 \mathrm{sec}, 52^{\circ} \mathrm{C}$ for $30 \mathrm{sec}$, and $72^{\circ} \mathrm{C}$ for $40 \mathrm{sec}$. The MSP results were evaluated using 2\% agarose gel electrophoresis.

\section{Quantitative bisulfite pyrosequencing}

DNA fragments were bisulfite converted and amplified with a primer set (Supplementary Figure S2A). The primers for PCR amplification and pyrosequencing were designed using PyroMark Assay Design 2.0 (Qiagen). The sequences of the PCR primers were as follows: forward primer: 5'-GAGAGGTTATTTGGATTTGGGTAGGAA-3'; reverse primer: 5'-CACCCAAAAAAATCAAAAAACCAAACT 
AC-3'; pyrosequencing primer: 5'-GGGTTTAGAGAG TAGTAAGA-3'. To determine the methylation level of $m i R-137,7 \mathrm{CpG}$ sites on $m i R-137$ were used for pyrosequencing analysis (Supplementary Figure S3). Quantitative DNA methylation analysis of pyrosequencing was carried out using a PyroMark Q24 System (Qiagen) and was analyzed using PyroQ-CpG 1.0.9.

\section{Xenograft animal studies}

Animal experiments were performed according to the Institutional Animal Care and Use Committee (IACUC) at the laboratory animal center of National Cheng Kung University. HCT116 stable clones with control vector or inducible $m i R-137$ were subcutaneously injected $\left(1 \times 10^{6}\right)$ into the left or right flank of 5- to 6-week old female NOD-SCID mice $(n=6)$. On the following day, the mice were fed $10 \mathrm{mM}$ IPTG in the drinking water to induce miR-137 expression. Tumor growth was measured using a caliper twice per week. Additionally, in another experiment, HCT116 stable clones with inducible miR-137 were subcutaneously injected $\left(1 \times 10^{6}\right)$ into the bilateral flank of 5- to 6-week old female NOD-SCID mice $(n=10)$. After the tumors reached approximately $100 \mathrm{~mm}^{3}$, the mice were separated into two groups randomly and fed regular water or $10 \mathrm{mM}$ IPTG in the drinking water to induce miR-137 expression. The tumor volume was calculated using the following equation: $\left(\right.$ length $\times$ width $\left.^{2}\right) / 2$. To determine the presence of apoptotic cells in the subcutaneous tumors, paraffin-embedded sections was used to perform the immunohistochemical staining using anti-Annexin V antibodies (AP6580b, ABGENT, San Diego, CA).

\section{Immunoblotting analysis}

Total protein isolated from cultured cell lines or tumor tissues from xenograft animal studies were lysed in modified RIPA buffer $(50 \mathrm{mM}$ Tris- $\mathrm{HCl}$ at $\mathrm{pH} 7.4$, $150 \mathrm{mM} \mathrm{NaCl}, 1 \mathrm{mM}$ EDTA, $1 \% \mathrm{NP}-40,0.25 \%$ sodium deoxycholate) with $1 \mathrm{mM}$ DTT, $10 \mathrm{mM} \mathrm{NaF}, 1 \mathrm{mM}$ PMSF, $1 \mu \mathrm{g} / \mathrm{ml}$ of aprotinin, $1 \mu \mathrm{g} / \mathrm{ml}$ of leupeptin, $1 \mathrm{mM}$ $\mathrm{Na}_{3} \mathrm{VO}_{4}$, and the phosphatase inhibitor cocktail to be analyzed. Following lysis, the lysates were resolved on an SDS-containing $10 \%$ polyacrylamide gel were transferred to a polyvinylidene difluoride nylon (PVDF) membrane and were probed with specific antibodies. The specific bands were detected by horseradish peroxidase-conjugated antibody and were revealed by Western Lighting ${ }^{\circledR}$ PlusECL (PerkinElmer, Waltham, MA) and X-ray film (Fujifilm, Tokyo, JP). The antibodies used were PARP-1 (F2), phospho-histone H3 and GAPDH from Santa Cruz Biotechnology (Santa Cruz, CA), Aurora-A [35C1] from GeneTex (Irvine, CA), and caspase-3 from IMGENEX (San Diego, CA).

\section{Immunochemical staining}

Formalin-fixed paraffin-embedded sections of xenograft tumor tissues were mounted on glass slides, deparaffinized with xylene and followed to rehydrate by a graded ethanol series. After microwaving in citratephosphate buffer ( $\mathrm{pH}$ 6.0) to retrieve the antigen, the slides were incubated with $3 \% \mathrm{H}_{2} \mathrm{O}_{2}$ at room temperature to block endogenous peroxidase activity. The sections were incubated with primary antibody at room temperature. Detection was followed with streptavidin-biotinylated peroxidase-conjugated reagents $\left(\mathrm{LSAB}^{+}\right.$kit: Dako, Carpentaria, CA) and 3,3' diaminobenzidine (DAB) as the chromogen, and the tissues were counterstained with hematoxylin.

\section{Immunofluorescence assay}

The cells were seeded on sterile glass coverslips for 18-24 hours. After treatment, the coverslips were removed from the medium and were washed once with PBS and then were fixed in $3.7 \%$ formaldehyde for 10 minutes at room temperature. The cells were rinsed in PBS and were permeabilized in $0.1 \%$ Tween-20/PBS for 10 minutes. The cells were then incubated with the primary antibodies diluted in $3 \% \mathrm{BSA} / \mathrm{PBS}$ for 1 hour at $37^{\circ} \mathrm{C}$, were washed in $0.1 \%$ Tween-20/PBS and were labeled for 1 hour at $37^{\circ} \mathrm{C}$ with appropriate Alexa 568-conjugated secondary antibodies. The cells were mounted in ProLong ${ }^{\circledR}$ Gold antifade reagent with DAPI (Invitrogen), and images were obtained with an immunofluorescence microscope.

\section{ACKNOWLEDGMENTS}

The authors thank Nature Publishing Group language editing for help with English editing. This work was supported by grants MOST 103-2320-B-006-037 and 104-2320-B-006-020-MY3 from Ministry of Science and Technology (Taipei, Taiwan), NCKUH-10406009 and NCKUH-10507002 from National Cheng Kung University Hospital (Tainan, Taiwan), and MOHW104-TD-B-111-06 and MOHW105-TDU-B-211-003 from Ministry of Health and Welfare (Taipei, Taiwan).

\section{CONFLICTS OF INTEREST}

The authors have declared that no conflicts of interest exists.

\section{GRANT SUPPORT}

This work was supported by grants MOST 1032320-B-006-037 and 104-2320-B-006-020-MY3 from Ministry of Science and Technology (Taipei, Taiwan), 
NCKUH-10406009 and NCKUH-10507002 from National Cheng Kung University Hospital (Tainan, Taiwan), and MOHW104-TD-B-111-06 and MOHW105TDU-B-211-003 from Ministry of Health and Welfare (Taipei, Taiwan).

\section{REFERENCES}

1. Pino MS, Chung DC. The chromosomal instability pathway in colon cancer. Gastroenterology. 2010; 138:2059-2072.

2. Leggett B, Whitehall V. Role of the serrated pathway in colorectal cancer pathogenesis. Gastroenterology. 2010; 138:2088-2100.

3. Boland CR, Goel A. Microsatellite instability in colorectal cancer. Gastroenterology. 2010; 138:2073-2087.e2073.

4. D'Assoro AB, Haddad T, Galanis E. Aurora-A Kinase as a Promising Therapeutic Target in Cancer. Front Oncol. 2015; 5:295.

5. Wang LH, Xiang J, Yan M, Zhang Y, Zhao Y, Yue CF, Xu J, Zheng FM, Chen JN, Kang Z, Chen TS, Xing D, Liu Q. The mitotic kinase Aurora-A induces mammary cell migration and breast cancer metastasis by activating the Cofilin-Factin pathway. Cancer Res. 2010; 70:9118-9128.

6. Wang D, Dubois RN. The role of COX-2 in intestinal inflammation and colorectal cancer. Oncogene. 2010; 29:781-788.

7. Williams CS, DuBois RN. Prostaglandin endoperoxide synthase: why two isoforms? Am J Physiol. 1996; 270:G393-400.

8. Al-Salihi MA, Terrece Pearman A, Doan T, Reichert EC, Rosenberg DW, Prescott SM, Stafforini DM, Topham MK. Transgenic expression of cyclooxygenase-2 in mouse intestine epithelium is insufficient to initiate tumorigenesis but promotes tumor progression. Cancer Lett. 2009; 273:225-232.

9. Chan AT, Ogino S, Fuchs CS. Aspirin and the risk of colorectal cancer in relation to the expression of COX-2. N Engl J Med. 2007; 356:2131-2142.

10. Hayes J, Peruzzi PP, Lawler S. MicroRNAs in cancer: biomarkers, functions and therapy. Trends Mol Med. 2014; 20:460-469.

11. Calin GA, Croce CM. MicroRNA signatures in human cancers. Nat Rev Cancer. 2006; 6:857-866.

12. Nohata N, Hanazawa T, Kinoshita T, Okamoto Y, Seki N. MicroRNAs function as tumor suppressors or oncogenes: aberrant expression of microRNAs in head and neck squamous cell carcinoma. Auris Nasus Larynx. 2013; 40:143-149.

13. Balaguer F, Link A, Lozano JJ, Cuatrecasas M, Nagasaka T, Boland CR, Goel A. Epigenetic silencing of miR-137 is an early event in colorectal carcinogenesis. Cancer Res. 2010; 70:6609-6618.

14. Bandres E, Agirre X, Bitarte N, Ramirez N, Zarate R, Roman-Gomez J, Prosper F, Garcia-Foncillas J. Epigenetic regulation of microRNA expression in colorectal cancer. Int J Cancer. 2009; 125:2737-2743.

15. Chen Q, Chen X, Zhang M, Fan Q, Luo S, Cao X. miR-137 is frequently down-regulated in gastric cancer and is a negative regulator of Cdc42. Dig Dis Sci. 2011; 56:2009-2016.

16. Chen DL, Wang DS, Wu WJ, Zeng ZL, Luo HY, Qiu MZ, Ren C, Zhang DS, Wang ZQ, Wang FH, Li YH, Kang TB, $\mathrm{Xu}$ RH. Overexpression of paxillin induced by miR-137 suppression promotes tumor progression and metastasis in colorectal cancer. Carcinogenesis. 2013; 34:803-811.

17. Liang L, Li X, Zhang X, Lv Z, He G, Zhao W, Ren X, Li Y, Bian X, Liao W, Liu W, Yang G, Ding Y. MicroRNA-137, an HMGA1 target, suppresses colorectal cancer cell invasion and metastasis in mice by directly targeting FMNL2. Gastroenterology. 2013; 144:624-635 e624.

18. Liu M, Lang N, Qiu M, Xu F, Li Q, Tang Q, Chen J, Chen X, Zhang S, Liu Z, Zhou J, Zhu Y, Deng Y, Zheng Y, Bi F. miR-137 targets Cdc42 expression, induces cell cycle G1 arrest and inhibits invasion in colorectal cancer cells. Int $\mathrm{J}$ Cancer. 2011; 128:1269-1279.

19. Smith AR, Marquez RT, Tsao WC, Pathak S, Roy A, Ping J, Wilkerson B, Lan L, Meng W, Neufeld KL, Sun XF, Xu L. Tumor suppressive microRNA-137 negatively regulates Musashi-1 and colorectal cancer progression. Oncotarget. 2015; 6:12558-12573. doi: 10.18632/oncotarget.3726.

20. Sun Y,Zhao X, Zhou Y,Hu Y. miR-124, miR-137 and miR-340 regulate colorectal cancer growth via inhibition of the Warburg effect. Oncology reports. 2012; 28:1346-1352.

21. Roelofs HM, Te Morsche RH, van Heumen BW, Nagengast FM, Peters WH. Over-expression of COX-2 mRNA in colorectal cancer. BMC Gastroenterol. 2014; 14:1.

22. Chen L, Wang X, Wang H, Li Y, Yan W, Han L, Zhang K, Zhang J, Wang Y, Feng Y, Pu P, Jiang T, Kang C, Jiang C. miR-137 is frequently down-regulated in glioblastoma and is a negative regulator of Cox-2. Eur J Cancer. 2012; 48:3104-3111.

23. Cheng Y, Li Y, Liu D, Zhang R, Zhang J. miR-137 effects on gastric carcinogenesis are mediated by targeting Cox-2activated PI3K/AKT signaling pathway. FEBS Lett. 2014; 588:3274-3281.

24. Zhu X, Li Y, Shen H, Li H, Long L, Hui L, Xu W. miR-137 inhibits the proliferation of lung cancer cells by targeting Cdc42 and Cdk6. FEBS Lett. 2013; 587:73-81.

25. Zheng X, Dong J, Gong T, Zhang Z, Wang Y, Li Y, Shang Y, Li K, Ren G, Feng B, Li J, Tian Q, Tang S, Sun L, Li M, Zhang $\mathrm{H}$, et al. MicroRNA library-based functional screening identified miR-137 as a suppresser of gastric cancer cell proliferation. J Cancer Res Clin Oncol. 2015; 141:785-795.

26. Langevin SM, Stone RA, Bunker $\mathrm{CH}$, Grandis JR, Sobol RW, Taioli E. MicroRNA-137 promoter methylation in oral rinses from patients with squamous cell carcinoma of the head and neck is associated with gender and body mass index. Carcinogenesis. 2010; 31:864-870. 
27. Langevin SM, Stone RA, Bunker CH, Lyons-Weiler MA, LaFramboise WA, Kelly L, Seethala RR, Grandis JR, Sobol RW, Taioli E. MicroRNA-137 promoter methylation is associated with poorer overall survival in patients with squamous cell carcinoma of the head and neck. Cancer. 2011; 117:1454-1462.

28. Bemis LT, Chen R, Amato CM, Classen EH, Robinson SE, Coffey DG, Erickson PF, Shellman YG, Robinson WA. MicroRNA-137 targets microphthalmia-associated transcription factor in melanoma cell lines. Cancer Res. 2008; 68:1362-1368.

29. Zhao Y, Li Y, Lou G, Zhao L, Xu Z, Zhang Y, He F. MiR-137 targets estrogen-related receptor alpha and impairs the proliferative and migratory capacity of breast cancer cells. PLoS One. 2012; 7:e39102.

30. Colucci PM, Yale SH, Rall CJ. Colorectal polyps. Clin Med Res. 2003; 1:261-262. 